\title{
The Barbizon School (1830-1870): Expanding the Landscape of the Modern Art Market
}

\author{
Lorinda Fraser* \\ University of Victoria \\ lorindafraser76@gmail.com
}

\begin{abstract}
From the 1830s to the 1870s, a cohort of French artists developed new approaches to landscape painting and became known collectively as the Barbizon School. This informal group of artists were proponents of an innovative way of painting in which nature was the central subject of their artworks. Moreover, nature was depicted without the classical idealization or polished refinement required by the French Academy at the time. Barbizon artists were also the catalysts for changes in how art was sold during the 19th century, paving the way for an open art market system that spread across the globe and continues unchanged to this day. Using Jean-Baptiste-Camille Corot (1796-1875) as a case study, I establish the ways in which the Barbizon School forged new stylistic and economic possibilities for later modern art movements, most prominently Impressionism, outside the purview of the French Academy. I also highlight the ways in which the Barbizon artists and their supporters contributed to the formation of a new art market founded upon an interconnected network of producers, consumers, and distributors.
\end{abstract}

Keywords: Barbizon; Camille Corot; landscape; 19th-century; art market

"Barbizon art was both heir and testator. It drew to itself the disparate riches of past traditions and passed them on, expanded and enriched."

—Robert L. Herbert, Barbizon Revisited

$\mathrm{F}$ rom the 1830s to the 1870s, the Barbizon School of French landscape painters initiated stylistic and commercial changes to the art world that continue today. The artists were proponents of an innovative way of painting, representing a transition from Romanticism's imagination, drama, and emotion to Naturalism's real-life objects depicted in their original settings, with nature as the central subject. Moreover, within Barbizon paintings, nature was depicted without the classical idealization or polished refinement required by the French Academy at the time. Barbizon artists were also the catalysts for changes in how art was sold during the nineteenth century, paving the way for an open art market system ${ }^{1}$ that spread across the globe and that continues unchanged to this day.

Using Jean-Baptiste-Camille Corot (1796-1875) as a case study, I argue that the Barbizon School forged new stylistic and economic possibilities for later modern art movements, most prominently Impressionism, outside the purview of the French Academy. I begin by introducing the Barbizon School, highlighting the ways in which they developed new and innovative approaches to landscape painting in the nineteenth century. I then discuss the ways in which the artists and their supporters

\footnotetext{
${ }^{*}$ I would like to express my sincere appreciation to Dr. Melissa Berry for her enthusiastic support and guidance, her determination to mould her students into professional scholars, and her contagious passion for the arts of 19th-century Europe. I would also like to thank Dr. Catherine Harding for her unfailing encouragement and mentorship throughout my undergraduate studies.

${ }^{1} \mathrm{An}$ art market in which the selling and buying of art is not limited to a restricted number of institutions, genres, subjects, or participants.
} 
made significant contributions to the formation of a new art market founded upon an interconnected network of producers, consumers, and distributors. Lastly, I assert that the artistic and commercial contributions made by the Barbizon School have been overshadowed by their Impressionist students and successors in art history literature and art exhibitions. I explore why attempts to revive the popularity of the Barbizon School with the general public and scholars alike have failed despite the artists' widespread and long-lasting contributions to the art world.

\section{Artists as Producers}

\section{Establishing the Barbizon School}

The term Barbizon School arose out of a need to distinguish the new group of French landscape painters that emerged during the early 19th century. At the time, they were commonly referred to as either the School of 1830 or the Fontainebleau School, but those terms were often confused with other movements and were eventually abandoned (Quinsac, 1980; Thomson, 1891). Instead, members assumed the name of the village of Barbizon, located on the edge of the Forest of Fontainebleau in north-central France. Though not every member of the Barbizon School resided in the village for extended periods, they all frequently joined the crowds of painters that flocked to the area in the early decades of the nineteenth century. There they painted the forest and the modest peasant life of its surrounding villages. The central figures of the Barbizon School included Jean-Baptiste-Camille (Camille) Corot, Théodore Rousseau (1812-1867), Jean-François Millet (1814-1875), Narcisse Diaz de la Peña (1807-1876), Constant Troyon (1810-1865), Charles-François Daubigny (1817-1878), and Jules Dupré (1811-1889). However, as I will demonstrate, their influence and mentorship spread beyond the purview of their French contemporaries, and their artistic and commercial impacts continue to be felt today.

\section{New Landscape Frontiers}

Just as they became precursors for the Impressionists, the Barbizon School also did not emerge out of a void. Three influential books primed French patrons and audiences for the popularity of a new form of landscape painting and the Barbizon School movement: classical landscape painter Pierre-Henri de Valenciennes' original approach to landscapes and outdoor painting in Elémens de Perspective Pratique in 1800 (Brettell, 1991), Charles Nodier's nationalistic 1920 series Voyages Pittoresques et Romantiques dans L'Ancienne France, and Abel Hugo's France Pittoresque of 1835, which promoted France as "contain[ing] all the riches of nature, combined with the treasures of intelligence and industry" (as cited in House, 2007, p. 79). Increased tourism and notions of the lone, liberated traveler were also common themes of intellectual discourse and illustrated publications at the time. These themes fostered romanticized conceptions of the artist as the definitive traveler and interpreter of the land (House, 2007).

During the early 19th century, the traditional styles of late 18th-century Neoclassicism and Romanticism were imposed upon all practicing artists by the Académie Royale de Peinture et de Sculpture (the Academy). During this time, only artists sanctioned and approved by the Academy were considered worthwhile producers, safe for investment by collectors and patrons. Artists' works were selected for inclusion in the Academy's annual Salon exhibition by previous winners trained and judged within the same system - continuously perpetuating the Academy's preferences and mandates. The domination of this program meant that artists had few or no alternative markets in which to exhibit their works, to establish their reputation, or to obtain patronage. Consequently, 
the Academy's influence shaped their creative output throughout their careers 2 It is within this environment that two painters, Valenciennes (1750-1819) and Achille Etna Michallon (1796-1822), studied together at the

textit'Ecole des Beaux-Arts in Paris and were trained to produce landscapes in the classical, Romantic tradition. Later, they chose to paint such works plein air ${ }^{3}$ However, at exhibition, the artists were careful to denote the pieces as mere preparatory sketches or "studies,' 4 which could later be polished and refined in the studio to Academy standards (Herbert, 1962, p. 19; Jones, 2008). Regardless of their training and experience, artists such as Valenciennes and Michallon had no option but to work within the limits set by the Academy in order to succeed in their profession.

Despite these restrictions, Valenciennes and Michallon's plein-air practices soon became popular with other painters. By the early 1820s, artist colonies inundated the Forest of Fontainebleau villages of Marlotte, Chailly, and Barbizon each summer (Herbert, 1962). As early as 1817, a French Academy Prix de Rome scholarship for landscape painting was established, formally signalling the country's worship of nature and depictions of the French countryside (Herbert, 1962). The invention of portable metal paint tubes in the early 1840\$5 and the expansion of the railway system from the mid-century onward allowed artists even greater freedom to travel and work in remote, outdoor locations (Ayres, 1985; House, 2007). As the 19th century progressed, landscape painting became prevalent in Salon exhibitions, increasing from 19 paintings of the Forest of Fontainebleau at the Salon of 1833 to 77 in 1880 (Kelly, 2008). More broadly, it is estimated that landscapes comprised $30 \%$ of the works exhibited in the Salon by the 1860s (Kelly, 2008). As prominent 19th-century British art dealer David Croal Thomson celebrates in The Barbizon School of Painters, at long last landscape painting was being recognized as "the last of the pictorial arts to be appreciated by the multitude" (1891, p. xiv). As I will demonstrate, the Barbizon artists were highly influential in perpetuating critical, scholarly, and public appreciation of the style and its primary subject matter-nature.

It was within the growing acceptance of landscape painting that the Barbizon School established its own distinct movement. The artists sought to escape the tensions and sense of alienation increasingly being experienced by artists in Paris, to express nationalistic pride for the landscape of France, and to assert themselves against the classical idealism of the Academy (Zimmermann, 2010). Further influenced by British topographical travel books, English painters such as John Constable (1776-1837), and 17th-century Dutch Lowlands paintings, the Barbizon painters sought a more sentimental form of expression than that of Constable, but also a landscape that was more visually and philosophically opposed to the industrialized city than Dutch artworks (Brettell, 1991; Champa, 1991b; Herbert, 1962; Zimmerman, 2010). As such, while the Barbizon style is predominately remembered for its plein-air technique, it also encompassed a fundamental shift to nature becoming valued as a primary subject instead of mere background to humanity. Furthermore, by depicting nature as it was found - in its natural state - Barbizon artists excluded demonstrative evidence of "the creative human mind" which moulded and ordered nature into romanticised forms and compositions (Herbert, 1962, p. 16). Instead, nature devoid of human figures and signs of modernization offered a space for individual introspection, as well as a rejection of the socio-political

\footnotetext{
${ }^{2}$ Inclusion of an artwork for a Salon exhibition in no way guaranteed the selection of an artist's pieces in subsequent years.

${ }^{3}$ To paint outdoors.

${ }^{4}$ Typically small and quickly executed, sketches or studies were used as preparatory exercises for expressing spontaneous design ideas, testing a project's composition, and/or demonstrating a proposed commission to a patron. They were produced prior to an artist's underdrawings and final fine art painting (Oil sketch, 2008).

${ }^{5}$ The first "collapsible metal tube" was patented in 1841 by American portraitist John G. Rand (Ayres, 1985, p. 132). Initially marketed by Thomas Brown, the design was franchised in 1842 by art supply firms such as Winsor \& Newton, who then patented the screw-top lid still in use today (Ayres, 1985).
} 
pressures of urban industrialization (House, 2007). Additionally, in contrast to romanticised beauty which was painstakingly refined to traditional tastes and expectations, Barbizon works were quickly executed using broad brushstrokes. Their colours were taken directly from the landscape itself, rather than a particular palette, so as to capture a specific moment or play of light. Stylistically, the Barbizon school "narrow[ed] the gap that had traditionally existed between the direct sketch and the finished studio picture" by seeking to capture nature realistically and without the need of embellishment beyond the inherent value and beauty of the natural landscape (Herbert, 1962, p. $15)$.

The Barbizon School was instrumental in the increased acceptance and popularity of French landscape painting, combining Dutch Lowlands and early 19th-century English aesthetics, topography, French regionalist ideologies, and the classical tradition with the compulsion to paint plein air (Herbert, 1962). As Herbert claimed in his seminal volume, Barbizon Revisited, this multifaceted legacy "led to fundamental changes in the appearance of painting" (1962, p. 63). As one of the two most influential artists of the Barbizon School, along with Rousseau, Corot was to later become "the most important teacher of landscape painters in the history of that art" and an ideal case study for exemplifying the influences of the Barbizon School (Brettell, 1991, p. 17).

\section{Case Study: Camille Corot}

Born in Paris in 1796, Camille Corot was a central figure in landscape painting and the Barbizon School during the 19th century. The son of well-off merchants, he attended nighttime drawing classes at the Académie Suisse in Paris during his late teens (Champa, 1991a). Despite his father's early demands that he become a man of business, Corot was eventually given a small allowance and the freedom to study full-time under classical landscape painters Michallon and Jean-Victor Bertin (1767-1842) (Champa, 1991a; Thomson, 1891). Under the tutelage of Michallon, Corot began painting plein air in 1822, travelling around Normandy, Fontainebleau, and outer Paris before spending 1825-1828 in Italy (Herbert, 1962). In 1827, he had his first painting accepted for exhibition in the French Salon. Thereafter, he had works selected for inclusion 35 out of the next 44 years, during which time he also won a total of two second-class medals and a Legion of Honour (Herbert, 1962). Between 1831 and 1834, Corot entered successive paintings of the Forest of Fontainebleau into Salon exhibitions, including Une Fôret (Fôret de Fontainebleau) (Figure 1). He gained increased attention from art critics when he sold two paintings to the Duc d'Orléans in 1838 and his first work to the French government in 1840, Setting Sun (Little Shepherd)/Le petit berger (Herbert, 1962).

In the late 1840s, Corot began simultaneously expanding the market for his artworks and expanding what was deemed acceptable by the French Academy in terms of stylistic technique and subject matter. In 1848, he made his first foray beyond the Salon by exhibiting in the third exhibition of L'Association des Artistes, held in the galleries of the Bazar Bonne-Nouvelle department store (Herbert, 1962). Simultaneously, he began gradually entering his plein-air paintings to the Salon: an Italian landscape, The Coliseum at Rome (1849), and a French landscape, Le port de la Rochelle (1851) (Figure 2). At the 1855 Paris Exposition Universelle, Corot, Rousseau, and Troyon each won first-class medals, signifying the Barbizon School's increased recognition by the established art community. Another triumph for Corot occurred that same year when Napoleon III purchased La charrette, souvenir de Marcoussis (1855) (Figure 3) (Champa, 1991a; Herbert, 1962). As a formally trained painter, Corot repeatedly proved his skill and merit by successfully producing artworks that stayed within the traditionalist confines of the Academy. By establishing his professional reputation, not to mention earning an income independent of his father, he was afforded the opportunity to gradually explore and expand his paintings beyond the subjects and 
stylistic techniques of his training - pushing at the boundaries imposed by the Academy.

Despite the Academy's increasing acceptance of Barbizon-style landscapes, Corot continued to work within two distinct formats: large canvases meant for Salon exhibition that emphasized his classical training and remained within the confines of Romanticist sentimentality and smaller paintings of nature that highlighted his growing Naturalist aesthetic and preferred Barbizon style. As an example, we can compare the size, subject matter, and painting techniques employed by Corot in two of his works completed during or around 1850. Une matinée, la danse des nymphes (1850) (Figure 4) is atmospheric; its mythological subjects dance through a precisely rendered landscape and the work measures a stately $98 \times 130 \mathrm{~cm}$. Alternatively, in Abandoned Quarry (ca. 1850) (Figure 5 ), rocks and trees are the central subject, and Corot's loose, sketch-like brushstrokes and warm earth tones prevail. A bent and toiling peasant woman to the central right can just be distinguished by the red of her headscarf. She is in no way the subject or focal point of the work; instead nature is given preference over her human form. Idealized humanity and nature have been abandoned for a realistic depiction of the French countryside as it appeared to the artist in the moment of creation. This piece measures only $29 \times 43 \mathrm{~cm}$, far more suitable dimensions for a middle-class Parisian's city home than Une matinée, la danse des nymphes. This highlights another key difference of the Barbizon style. By keeping their pieces small for ease of portability, Barbizon artists such as Corot could also create more pieces within a given time. Subsequently, works such as Abandoned Quarry could be priced at lower price points and fit into more modest-sized homes, expanding the market for potential art buyers beyond the wealthy elite. Comparing these two works of approximately the same time exemplifies how Corot strategically managed his artistic output to influence and alter the confines of the Salon system and the art market. Une matinée, la danse des nymphes comfortably met the criteria of those confines in size, subject matter, and aesthetic. In contrast, Abandoned Quarry pushed the Academy, art critics, and the public to consider new possibilities for defining what art should and could be, what subjects were appropriate and desirable, and the ways in which art could be sold to a broader audience.

Camille Corot provides the ideal case study for exemplifying how the Barbizon School altered expectations for fine art in the 19th century. Having gained widespread recognition during the 1840s, he was able to obtain significant commissions and patronage during his lifetime. As an early proponent and central figure of 19th-century French landscape, Corot taught two generations of painters - later Barbizon School artists such as Daubigny and Eugène Boudein (1824-1898) as well as emerging Impressionists Berthe Morisot (1841-1895) and Camille Pissarro (1830-1903). He shared with each of them his five-decade relationship with the Forest of Fontainebleau, painting plein air, and emotive Naturalist realism. While much scholarship and press have been allocated to the Impressionists for their more dramatic break from the Salon system, as we have seen, they were not without artistic and commercial predecessors. Corot and his Barbizon contemporaries began working both within and outside of the Salon as early as the 1830s. By establishing his reputation as a skilled classical artist via the Academy alongside his plein-air landscapes, Corot gradually influenced the consciousness of Salon juries over a series of yearly submissions. He set the stage for the acceptance of a broader range of aesthetics, techniques, and subject matter beyond refined, classical, Romantic traditions. For example, in 1889, Corot and the Barbizon artists were featured in no less than three major art exhibitions: 21 paintings by Corot were exhibited at London's Goupil Gallery, an exhibition of Barbizon works was held by the Barye Monument Society in New York, and 52 works were exhibited at the 1889 Paris Exposition Universelle (Rathbone, 1962; Thomson, 1891). Simultaneously, Corot's reputation also contributed to the lessening of the Academy's monopoly over the French art market by imbuing value and respectability upon those collectors and dealers who purchased and distributed his Barbizon-style paintings. During and shortly following their careers, the Barbizon artists were critically and publicly recognized as the producers of a new kind 
of art, art that could be bought and sold by a new type of consumer in a rapidly evolving market. As we will see, such acclaim was not to last.

\section{Collectors as Consumers}

Following France's Revolution of July 1830, intellectuals within the Orléanist faction were the first collectors of Barbizon art outside of the Salon (Herbert, 1962). They were attracted to the School's radical approach to landscape painting and resistance to the Salon's traditionalist system. The spokesperson for the faction, Duc d'Orléans Ferdinand Philippe, was an avid collector of the Barbizon School during the 1830s. Following Ferdinand Philippe's death in 1842, Paul Périer, Paul Barroilhet, and Paul Collot then asserted themselves as the preeminent collectors of avant-gard $\AA^{6}$ Naturalist landscape paintings, namely from the Barbizon School (Kelly, 2004). From similar middle-class backgrounds, the three collectors each developed close relationships with their favoured artists. Like the Orléanist faction, they seemed particularly drawn to works that had been refused by the Salon, both out of loyalty to the Barbizon painters, but also as an affront to the traditionalist values perpetuated by the Academy and its jury system (Kelly, 2004). The most prestigious and affluent of these 1840s collectors was Paul Périer. A banker with inherited money to initially support his collecting, Périer brought himself to near financial ruin by the middle of the 1840s through risky land speculation deals and his immense accumulation of old masters and modern artworks (Kelly, 2004). In 1846, he was forced to sell much of his collection at auction, liquidating over 50 paintings and drawings (Kelly, 2004). This event attracted substantial interest from art critics and raised the prestige and prices of Barbizon artworks, some as high as 50\% (Kelly, 2004). One of the Barbizon's most celebrated collectors was operatic baritone Paul Barroilhet. Upon leaving the Paris Opera in 1847, Barroilhet devoted himself to art collecting, buying and selling off a minimum of six collections between 1855 and the mid-1860s (Kelly, 2004). Much more private than his contemporaries, the haberdasher ${ }^{7}$ Paul Collot focused his attention on forming one of Paris' most notable modern art collections during the late 1840s and early 1850s (Kelly, 2004). Though little is known about Collot, it is assumed that, like his contemporaries, it was financial difficulties that likely forced him to sell 74 of his beloved artworks in 1852, at the first major auction of the Hôtel Drouot auction house (Kelly, 2004). Though the support of the Barbizon School by Périer, Barroilhet, and Collot was relatively short lived, they were key consumers of Barbizon artworks. Their continuous buying and selling kept Barbizon artists in the consciousness of the public and of future buyers, and over time Barbizon paintings increased in value as a result of this activity (Kelly, 2004). By purchasing artworks directly from the artists whenever possible or art dealers when necessary, Ferdinand Philippe, Périer, Barroilhet, and Collot circumvented the Salon system and were significantly influential in the establishment of the open French art market during the 19th century.

\section{Dealers as Distributors}

In the 1860s, art dealer Paul Durand-Ruel (1831-1922) took on the role of championing Barbizon School painters outside the Salon system. Arguably the most innovative and influential dealer of the 19th-century, Durand-Ruel is best known for his support of Barbizon and Impressionist artists. Early in his career, he developed several strategies for promoting the work of his chosen artists, based on seven principles:

\footnotetext{
${ }^{6}$ To be new and/or experimental.

${ }^{7} \mathrm{~A}$ seller of sewing items or notions, such as buttons and thread.
} 
the protection of the art first and foremost; the exclusivity of the artists' work; the founding of art reviews; the marriage of the worlds of art and finance; the staging of solo rather than group exhibitions; a network of international galleries, and regular unrestricted access to his galleries and apartment. (Durand-Ruel \& Durand-Ruel, 2015, p. 41)

Acting as the Barbizon School's chief buyer and source of moral support from the late 1860s onwards, Durand-Ruel was instrumental in strategically securing public interest for their paintings (Durand-Ruel \& Durand-Ruel, 2015).

Replacing his father as head of the Durand-Ruel Gallery in 1865, Durand-Ruel soon moved the business to 16, rue Laffitte/11, rue Le Peletier (nicknamed "la rue des tableaux/the street of pictures") within the artistic centre of the Parisian art community (Patry, Robbins, Riopelle, Rishel, \& Thompson, 2015, p. 22). Though an avid collector of all Barbizon School artists, Durand-Ruel clearly favoured Corot, buying 225 of the artist's works from fellow dealers and collectors between 1866 and 1873 (Kelly, 2015). Already well established by this time, Corot's paintings regularly made Durand-Ruel profits of $20 \%$ to $30 \%$, but occasionally works such as Une matinée, la danse des nymphes doubled his return (Kelly, 2015). Though most widely known as the Impressionists' primary art dealer, Durand-Ruel once wrote that "the only artist that he admired as much as Delacroix was Corot" (Kelly, 2015, p. 63). He praised Corot on a purely artistic level, responding to his meditative Naturalistic style, favouring it above even that of his much lauded Impressionists (Kelly, 2015).

Durand-Ruel's innovative approaches and strategies for supporting his artists allowed him to hold monopolized control over several artists' oeuvres 8 effectively controlling their prices and steadily increasing them over time (Kelly, 2015). He used an artist's biography to garner interest from collectors, catering to the tastes and nationalistic ideologies of buyers in London, Paris, throughout the rest of Europe, and in the United States (Kelly, 2015). In January 1869, Durand-Ruel established a European-wide monthly arts magazine La Revue International de L'Art et de la Curiosité to publish articles in support of the artists he promoted (Kelly, 2015). The magazine provided a venue for maintaining ongoing dialogue and discourse about an artist, their biography, and their work (Kelly, 2015). Durand-Ruel also offered public lecture series within his gallery space to inform potential buyers. Often those lectures would then be published in La Revue, further reinforcing a sense of expertise and ongoing media exposure in support of the movement. In 1878, he organized an exhibition of 382 Barbizon paintings at his rue Laffitte gallery during the Paris Exposition Universelle (Kelly, 2015), drawing numerous positive reviews from critics and art aficionados, if not large public crowds. Unsurprisingly, dealers and collectors saw an increase in prices for Barbizon paintings in the following years (Kelly, 2015).

In his memoirs, Durand-Ruel wrote that his career, indeed, his personal and financial life, had been "dominated by two campaigns: the first to raise the value of 'the beautiful [Barbizon School],' and the second to increase support for his cherished Impressionists" (cited in Kelly, 2015, p. 56). Through his one-artist and group shows, monopolization of specific artists, network of relationships with critics and other dealers, and international connections, Durand-Ruel made long-lasting changes to the 19th-century art market for artists of the Barbizon School and their successors. In return, the Barbizon School artists, Corot in particular, were instrumental in establishing the role of art dealer as a respectable, legitimate profession divorced from the crass realities of commerce. They provided a balanced model of academically-trained yet avant-garde producers on whom consumers, collectors, and dealers could depend to be fiscally stable even with art purchased outside the relative security of the Academy (Herbert, 1962). Barbizon artists were simultaneously altering what was deemed acceptable within the art community and permanently influencing our tastes and preferences. To

${ }^{8}$ An artist's body of work. 
put it plainly, the Barbizon School's artists' methodical and seemingly moderate transitions made Impressionism and other modern art movements possible. However, I contend that they have not been given credit for the radical long-term changes they are responsible for because their nuanced, methodical, and moderate approach has not attracted the attention that they deserve.

\section{The Barbizons Eclipsed}

Despite their influence upon the subjects, styles, and commerce of art in 19th-century France, the Barbizon School has fallen into obscurity. While entire art history courses are devoted to the Impressionists, few of today's emerging scholars are introduced to their predecessors. In the foreword to Robert Herbert's Barbizon Revisited, Perry T. Rathbone claims that the 1962 exhibition catalogue was "only the second serious attempt in the twentieth century to appraise the whole achievement of the school in extenso" (p. 10). Furthermore, according to Rathbone, most other books written on French art were inadequate to "bring into critical focus, to understand and enjoy anew... a school which in a sense lies buried, but refuses to die" (as cited in Herbert, 1962, p. 10). Herbert pondered whether the Barbizon artists were considered too "sentimental," particularly by post-World War audiences fascinated with depictions of modern urban life (1962, p. 15), in other words, those seeking freedom within the anonymity of the city rather than the solitude of the countryside. In the late 19th-century, David Croal Thomson predicted that "to be properly appreciated, [Corot's work] requires more knowledge; but as the world becomes older and wiser, this will gradually vanish as an objection to his work" (1891, p. 5). Sadly, this additional acquired knowledge has yet to come to fruition. We continue to wait for "another generation who shall comprehend and gladly accept them," acknowledging the breadth and importance of the Barbizon School's contributions to the landscape of painting and the art market (Thomson, 1891, p. xv). More than a century later, and 25 years after Herbert's "epochal" Barbizon Revisited exhibition, most literature on the Barbizon School was written in the 19th century, and the relationship between the Barbizon artists and the Impressionists has been largely ignored (Champa, 1991b, p. 23). In The Rise of Landscape Painting in France: Corot to Monet, Kermit Champa (1991b) claims that the 1991 exhibition was the first to make such connections explicit. Even the naming of the exhibition "recognize[d] by [its] very subtitle how little the public understands the prehistory of Impressionism in French landscape painting," thus effectively exploiting Monet's widespread name recognition (Brettell, 1991, p. 20). Even that attempt at a revival of recognition is, yet again, 25 years in the past.

While respectfully acknowledging the validity of the scholars above, I argue that the Barbizon school artists were too subtle in their skillful manipulation of the Academy system. They were so successful, in fact, that their influence was difficult to detect then and has become even more challenging to distinguish now with the distance of time. Instead, the radical approaches and highly publicized, flagrant defiance of the Academy by the Impressionists lingers in our myths, memories, and artistic discourses. Returning once again to Corot as an example, we are presented with a quiet bachelor who remained close to his sister until her death and who generously supported numerous charities and friends, including the widow of his colleague and friend J. F. Millet (Thomson, 1891). More broadly, among his many students he was universally known as Père Corot for his selfless mentorship (Thomson, 1891). Corot's is not a biography of legendary exploits or political activism. His quiet but powerful transformation of the world of art was just as understated as his life, but no less appreciated by those who knew him. I argue that it was Corot and the Barbizon School's nuanced but highly effective undermining of the French Academy system, from within, that is simultaneously their greatest legacy but also the ultimate source of their current obscurity. 


\section{Conclusion}

The Barbizon School holds a unique place in the transitioning art world of 19th-century France. They were the first artists to publicly designate their Naturalist paintings as finished artworks while also highlighting nature as their central subject. As such, Barbizon artists served as strategic catalysts in the process of expanding Academy expectations and notions of what constituted fine art beyond Romanticist and Neoclassical aesthetics and ideologies (Herbert, 1962). Corot in particular was a crucial mentor to other 19th-century painters, most significantly the Impressionists, setting "the standards for landscape practice for half a century" (Champa, 1991a, p. 116). Most importantly, by working within the Salon system, slowly introducing images of the Forest of Fontainebleau and plein-air pieces that appeared to conform to traditional ideals, Barbizon artists created a legacy for future modern art movements and the art market. Despite being all too frequently eclipsed by the fame of their Impressionist successors, the Barbizon artists were undeniable catalysts for change. In capitalizing on their well-established prestige and respectability, the artists, their collectors, their distributors, and their successors were able to develop a network of economic and personal relationships for expanding what was available on the art market and how it could be sold. By selling art beyond the purview of the Salon, the Barbizon artists created new financial and commercial possibilities that spread far beyond the markets of France and continue unchanged today. 


\section{References}

Ayres, J. (1985). The artist's craft: A history of tools, techniques and materials. Oxford, England: Phaidon.

Brettell, R. R. (1991). Introduction. In K. S. Champa (Ed.), The rise of landscape painting in France: Corot to Monet (pp. 15-21). New York, NY: Currier Gallery of Art.

Champa, K. S. (1991a). Catalogue entries. In K. S. Champa (Ed.), The rise of landscape painting in France: Corot to Monet (pp. 99-225). New York, NY: Currier Gallery of Art.

Champa, K. S. (1991b). The rise of landscape painting in France. In K. S. Champa (Ed.), The rise of landscape painting in France: Corot to Monet (pp. 23-63). New York, NY: Currier Gallery of Art.

Durand-Ruel, P-L., \& Durand-Ruel, F. (2015). Paul Durand-Ruel (1831-1922): A portrait. In S. Patry (Ed.), Inventing Impressionism: Paul Durand-Ruel and the modern art market (pp. 30-53). London, England: National Gallery Company.

Herbert, R. L. (1962). Barbizon revisited: Essay and catalogue. New York, NY: Clarke and Way.

House, J. (2007). Framing the landscape. In M. Tompkins Lewis (Ed.), Critical readings in Impressionism and Post-Impressionism: An anthology (pp. 77-99). Berkeley, CA: University of California Press.

Jones, K. (2008). Landscapes, legends, souvenirs, fantasies: The Forest of Fontainebleau in the nineteenth century. In K. Jones (Ed.), In the Forest of Fontainebleau: Painters and photographers from Corot to Monet (pp. 2-139). New Haven, CT: Yale University Press.

Kelly, S. (2004). Early patrons of the Barbizon School: The 1840s. Journal of the History of Collections 16(2), 161-172. https://doi-org.ezproxy.library.uvic.ca/10.1093/jhc/16.2.161

Kelly, S. (2008). The mystery of the forest: Paintings of Fontainebleau at the Salon. In K. Jones, (Ed.), In the Forest of Fontainebleau: Painters and photographers from Corot to Monet (pp. 140-151). New Haven, CT: Yale University Press.

Kelly, S. (2015). Durand-Ruel and 'La Belle Ecole' of 1830. In S. Patry (Ed.), Inventing Impressionism: Paul Durand-Ruel and the modern art market (pp. 54-75). London, England: National Gallery Company.

Oil sketch. (2008). In G. Ward (Ed.), The Grove encyclopedia of materials and techniques in art. Retrieved from http://www.oxfordreference.com

Patry, S., Robbins, A., Riopelle, C., Rishel, J. J., \& Thompson, J. A. (2015). Paul Durand-Ruel, an 'unrepentant risk-taker.' In S. Patry (Ed.), Inventing Impressionism: Paul Durand-Ruel and the modern art market (pp. 10-29). London, England: National Gallery Company.

Quinsac, A-P. (1980). The School of Barbizon. In S. Bijutsukan (Ed.), Millet, Corot and the school of Barbizon: The Seibu Museum, 15 March-14 April, 1980 (n.p.). Tokyo, Japan: Seibu Museum.

Rathbone, P. T. (1962). Foreword. In Herbert, R. L., Barbizon revisited: Essay and catalogue (pp. 10-13). New York, NY: Clarke and Way.

Thomson, D. C. (1891). The Barbizon School of painters: Corot, Rousseau, Diaz, Millet, Daubigny, etc. London, England: Chapman and Hall Limited.

Zimmermann, M. F. (2010). Radical alienation-radical involvement: A brief history of subjectivity and landscape up to Impressionism. In S. F. Eisenman (Ed.), From Corot to Monet: The ecology of Impressionism (pp. 107-119). New York, NY: Skira. 
Figures

Figure 1

Jean-Baptise-Camille Corot, Une fôret (Fôret de Fontainebleau), 1834, oil on canvas, 175.6 x 242.6 cm. Available at: https://www.nga.gov/content/ngaweb/Collection/art-object-page.46584.html, Collection of the National Gallery of Art, U.S.A.

Figure 2

Jean-Baptise-Camille Corot, Le port de la Rochelle (The Harbor of La Rochelle), 1851, oil on canvas, $50.5 \times 71.8 \mathrm{~cm}$. Available at: http://artgallery.yale.edu/collections/objects/52867, Collection of the Yale University Art Gallery

Figure 3

Jean-Baptise-Camille Corot, La charrette, souvenir de Marcoussis, 1855, oil on canvas, $98.2 \times 130.3$ cm. Available at: http://www.musee-orsay.fr/en/collections/index-of-works/notice.html?no_cache $=1 \& z s z=5 \& \ln u m=\&$ nnumid $=16678$, Collection of the Musée d'Orsay

Figure 4

Jean-Baptise-Camille Corot, Une matinée, la danse des nymphes, 1850, oil on canvas, 97.7 x 130.5 cm. Available at: http://www.musee-orsay.fr/en/collections/index-of-works/notice.html?no_cache $=1 \&$ nnumid $=000243 \& \mathrm{cHash}=\mathrm{c} 18188 \mathrm{~b} 082$, Collection of the Musée d'Orsay

Figure 5

Jean-Baptise-Camille Corot, Abandoned Quarry, ca. 1850, oil on paper on canvas, 29 x $43 \mathrm{~cm}$. Available at: https://demesdagcollectie.nl/en/collection/hwm0062, The Mesdag Collection, The Hague 